\title{
SOCIO-ECONOMIC CORRELATIVES OF SCHOOL DROPOUTS AMONG MUSLIM BOYS AND GIRLS
}

\section{Musarrath Banu K.*}

The concept of development needs to be redefined, because conventional indicators of development such as percapita gross domestic product or consumption expenditure or poverty rates need not necessarily translate into a better life for all people. The high economic development of the region should be accessible to all the sections of the society. Hence the development should be people oriented rather than things oriented.

The concept of human development include three main components, they longevity or the capacity to live a long healthy life, education, the ability to read and write and acquire knowledge and skills and command over economic resources, sufficient to provide a decent standard of living. Once these capacities are assured then other opportunities in life will follow.

One of the most important components of human development is education. Education is recognized as a fundamental human right, along with other necessities, such as food shelter, and water, in the universal declaration on human rights

* Dept. of Sociology, Al-Ameen Arts, Science and Commerce College, Bangalore-560027. mkbanu@hotmail.com 
(1948). Education has the empowering ability. It creates awareness regarding ones' rights as the citizen of a democracy and helps one to make informed choices.

India is a multigroup pluralistic social system. There cannot be a uniform yardstick to talk about the over all development of the nation. Different groups have attained different levels of development in India. Based on their socio-economic, religious and cultural underpinnings, there is a need to adopt different strategies for the development of different groups,

The agenda here is to discuss the educational status of Muslims in India. Research has shown a very low level of socio-economic and educational development attained by the community. According to Sachar Committee report that 25\% of the Muslim children in the 6-14 years age group have either never attended school or have dropped out. The representation of Muslims is only $3 \%$ in IAS, $1.8 \%$ in IFS, and $4 \%$ in the IPS. Hence Indian Muslims are below the conditions of even scheduled castes and scheduled tribes.

\section{Some of the Socio-Economic Correlatives of School Dropouts among Muslim Boys and Girls}

The present study was conducted to look into the socio-economic correlatives of school dropouts among the Muslim boys and girls. The sample size of the study was 100 consisting both male and female respondents in the age group of 10-20 years, separate interviews were conducted with the parents of the respondents. Two major localities comprising of poorer sections of the Muslim population in Bangalore city such as the Bada Makan area on Hosur road and Yarabnagar near Banshankari were selected for data collection. Apart from these two areas, a part of Kammanahalli and Mavalli and City Market area comprising of poorer sections of Muslim population were also included, in an attempt to give universal representation to data collected.

It is a comparative study which enquires into the socio-economic correlatives of school dropouts among the Muslims boys and girls, their attitude towards education, awareness about the importance of education, role of community and political leadership, awareness about the Quranic injunctions regarding the importance of education, attitude towards girls' education and employment, parents' interest in the education of the boys and girls and many other related factors..

The interviews were conducted at the residences, places of work, some times near playgrounds, streets and market areas of the locality where generally male dropouts 
were found, after the interview they would take the researcher to their residence for an interview with their parents, generally mother, sometimes father and both the parents. It may be noted that the place of work, which was generally a mechanic shop etc., in many cases was close to the residence of the dropouts. On an average each interview took about 45 minutes to one hour depending on the nature of the respondents. Though the questions were in English, the respondents were interviewed in Urdu, a language that is the mother tongue of Muslims in Bangalore city.

\section{Some of the Findings of the Study}

As far as the education of the dropout's parents is concerned, in majority of the cases both the parents of both male and female dropouts are illiterate. In the case of the male dropouts $68 \%$ of the fathers and $66 \%$ of mothers are illiterate. Similarly $76 \%$ of the fathers and $82 \%$ of the mothers are illiterate in the female dropouts case.

Parents' occupation: All most all dropouts both male and female come from homes where fathers are either in skilled or unskilled occupations, such as plumbing, tyres works, lathe works, coolie work, carpentry, auto driving, bus conductors, moulding, mechanic works, tinkering, horse cart riding, agarbathi packing, working as security in offices, etc.

Table 1. Table indicating literacy level of the dropouts.

\begin{tabular}{|c|c|c|c|c|c|}
\hline SI.No. & $\begin{array}{c}\text { Level of } \\
\text { literacy }\end{array}$ & Male & $\%$ & Female & $\%$ \\
\hline 1 & Less than 3rd & 05 & 10 & 04 & 08 \\
2 & $4-5$ & 17 & 34 & 05 & 10 \\
3 & $6-7$ & 16 & 32 & 29 & 58 \\
4 & $8-9$ & 12 & 24 & 12 & 24 \\
\hline Total & & 50 & & 50 & \\
\hline
\end{tabular}

One of the glaring facts, which emerge here, is that while the male dropouts have occurred more in 4-5 and 6-7 standard level, the female dropouts are the highest in $6-7^{\text {th }}$ standard level. It may be noted that girls discontinue after $7^{\text {th }}$. Where as the boys dropouts at $4^{\text {th }}, 5^{\text {th }}, 6^{\text {th }}$ and $7^{\text {th }}$ standard level. 
Table 2. Table indicating total family income per month.

\begin{tabular}{|c|l|c|c|c|c|}
\hline \multirow{2}{*}{$\begin{array}{c}\text { SI. } \\
\text { No. }\end{array}$} & $\begin{array}{c}\text { Level of income } \\
\text { Rs. }\end{array}$ & \multicolumn{2}{|c|}{$\begin{array}{c}\text { Family of the male } \\
\text { dropout Income }\end{array}$} & \multicolumn{2}{|c|}{$\begin{array}{c}\text { Family of the female } \\
\text { dropout }\end{array}$} \\
\cline { 2 - 6 } & Income & $\%$ & Income & $\%$ \\
\hline 1 & Less than 1000 & $\mathrm{Nil}$ & $\mathrm{Nil}$ & 07 & 14 \\
2 & $1000-3000$ & 13 & 26 & 15 & 30 \\
3 & $3000-5000$ & 16 & 32 & 08 & 16 \\
5 & $5000-7000$ & 08 & 16 & 13 & 26 \\
6 & $7000-9000$ & 03 & 06 & 06 & 12 \\
7 & $9000-11000$ & 01 & 02 & $\mathrm{Nil}$ & $\mathrm{Nil}$ \\
\hline Total & Above 11000 & 09 & 18 & 01 & 02 \\
\hline
\end{tabular}

It may be noted that the female dropouts are comparatively poorer than their male counterparts. Highest percentage of male dropouts are found in the income range of Rs.3000-5000 and the highest percentage of female dropouts are found in the income range of Rs. 1000-3000, 18\% of the male dropouts are found in the income level of above Rs. 11,000 , whereas only $2 \%$ of the female dropouts come under that level. In fact one male dropout has family income of Rs. 1,30,000 per month. It may be noted once again that inspite of relative poverty in comparison to their male counterparts higher percentage of females were attending school in class 5 and above.

Table 3.Table indicating the number of respondents who are gainfully employed.

\begin{tabular}{|c|c|c|c|c|c|}
\hline SI.No. & Response & $\begin{array}{c}\text { Male } \\
\text { respondents }\end{array}$ & $\%$ & $\begin{array}{c}\text { Female } \\
\text { Respondents }\end{array}$ & $\%$ \\
\hline 1 & Yes & 47 & 94 & 12 & 24 \\
2 & No & 03 & 06 & 38 & 76 \\
\hline Total & & 50 & & 50 & \\
\hline
\end{tabular}

It is a fact worth noting that large majority (94\%) of male dropouts are gainfully employed and large majority of female dropouts (76\%) are not gainfully employed. 


\section{Type of paid work done by the dropouts:}

Various types of paid work done by male dropouts are; lathe works, carpentry, polish making, embroidery, as helpers in teashops, motor parts, chappal shop, mechanic works, tailoring, box making etc. Whereas the female dropouts are engaged in paid work such as Maid Servant, Beedi Rolling, Agarbathi rolling, Rolling of incense sticks, Jasmine Flower tying, working in Garments factory Etc.

Table 4. showing the wages of the respondents per month (From those noted as gainfully employed).

\begin{tabular}{|c|l|c|c|c|c|}
\hline SI.No. & \multicolumn{1}{|c|}{ Wages Rs. } & Males & $\%$ & Females & $\%$ \\
\hline 1 & 500 & 11 & 23 & 06 & 50 \\
2 & $500-1000$ & 15 & 32 & 03 & 25 \\
3 & $1000-2000$ & 09 & 19 & 01 & 08 \\
4 & $2000-3000$ & 07 & 15 & 02 & 17 \\
5 & More than 3000 & 05 & 11 & $\mathrm{Nil}$ & $\mathrm{Nil}$ \\
\hline Total & & 47 & & 12 & \\
\hline
\end{tabular}

It may be noted that highest percentage of male dropouts (32\%) earn wages between Rs. 500 - 1000 per month, whereas highest percentage of female dropouts (50\%) earn Rs. 500 per month.

Table 5. Table indicating the school attended by the respondents.

\begin{tabular}{|c|c|c|c|c|c|}
\hline $\begin{array}{c}\text { SI. } \\
\text { No. }\end{array}$ & $\begin{array}{c}\text { Type of } \\
\text { school }\end{array}$ & $\begin{array}{c}\text { Male } \\
\text { Respondents }\end{array}$ & $\%$ & $\begin{array}{c}\text { Female } \\
\text { Respondents }\end{array}$ & $\%$ \\
\hline 1 & Govt. & 41 & 82 & 43 & 86 \\
2 & Private & 07 & 14 & 06 & 12 \\
3 & Aided & 02 & 04 & 01 & 02 \\
\hline Total &. & 50 & & 50 & \\
\hline
\end{tabular}

Large majority of both male and female dropouts attended Government schools. 
Table 6. Table medium in which the respondents studied.

\begin{tabular}{|c|c|c|c|c|c|}
\hline SI.No. & Medium & Male & $\%$ & Female & $\%$ \\
\hline 1 & English & 13 & 26 & 07 & 14 \\
2 & Urdu & 31 & 62 & 39 & 78 \\
3 & Kannada & 05 & 10 & 04 & 08 \\
4 & Others & 01 & 02 & Nil & Nil \\
\hline Total & & 50 & & 50 & \\
\hline
\end{tabular}

Higher percentage of male dropouts who attended English medium schools than female dropouts. However highest percentage of both the male and female dropouts attended Urdu medium schools.

Table 7. Table indicating the distance to school attended by the respondents.

\begin{tabular}{|c|l|c|c|c|c|}
\hline $\begin{array}{c}\text { Sl. } \\
\text { No. }\end{array}$ & $\begin{array}{c}\text { Distance in } \\
\text { k.m. }\end{array}$ & $\begin{array}{c}\text { Male } \\
\text { respondents }\end{array}$ & $\%$ & $\begin{array}{c}\text { Female } \\
\text { respondents }\end{array}$ & $\%$ \\
\hline 1 & Less than 5 & 43 & 86 & 43 & 86 \\
2 & $10 \mathrm{k.m}$. & 07 & 14 & 07 & $\mathrm{Nil}$ \\
3 & More than $10 \mathrm{k.m}$. & $\mathrm{Nil}$ & $\mathrm{Nil}$ & $\mathrm{Nil}$ \\
\hline Total & & 50 & & 50 & \\
\hline
\end{tabular}

Majority of the school dropouts attended school close to their home.

Table 8. Table indicating awareness of the respondents about the availability of scholarship facility.

\begin{tabular}{|c|c|c|c|c|c|}
\hline SI.No. & Response & Male respondents & $\%$ & Female respondents & $\%$ \\
\hline 1 & Yes & 06 & 12 & 07 & 14 \\
2 & No & 44 & 88 & 43 & 86 \\
\hline Total & & 50 & & 50 & \\
\hline
\end{tabular}

Very few dropouts have made use of the scholarships facility, and there is not much awareness about the availability of scholarship 
Table 9.Table showing the reason for discontinuation of school by the respondents

\begin{tabular}{|c|l|c|c|c|c|}
\hline SI.No. & \multicolumn{1}{|c|}{ Reasons } & Males & $\%$ & Females & $\%$ \\
\hline 1 & Economic compulsion & 12 & 18 & 19 & 26 \\
2 & Loss of interest & 39 & 59 & 15 & 21 \\
3 & Parents force & 03 & 05 & 22 & 31 \\
4 & Bad company & 08 & 12 & $\mathrm{Nil}$ & $\mathrm{Nil}$ \\
5 & Other & 04 & 06 & 16 & 22 \\
\hline Total & & 66 & & 72 & \\
\hline
\end{tabular}

Note: There are more than one reasons for dropping out.

1) It may be noted that highest percentage (59\%) of male dropouts have taken place due to loss of interest, highest percentage (31\%) of female dropouts have occurred due to parent's force. There is a higher percentage of females (26\%) who have dropped out due to economic compulsions than males (18\%). $12 \%$ of the males have dropped out due bad company and none of the females have dropped out due to the bad company.

2) It may also be noted that there are more than one reasons given by the dropouts. In the last category of other reasons may be included long distance to school, no school after $8^{\text {Th }}$ near house, no proper teaching in the school, the boy was spending more time in playing cricket than in school, friends left the school so the boy also left.

3) In the case of females brothers have played a very important role in forcing them to leave school, especially after attaining puberty, failing more then one time in the same class.

4) It should also be taken note of that a big number of females have left school due the fact that there is no school in the close vicinity after $7^{\text {th }}$ standard.

Table 10. Table indicating the ability of the respondents to read and write.

\begin{tabular}{|c|c|c|c|c|c|}
\hline SI.No. & Response & Male respondents & $\%$ & Female respondents & $\%$ \\
\hline 1 & Yes & 16 & 32 & 20 & 40 \\
2 & No & 34 & 68 & 30 & 60 \\
\hline Total & & 50 & & 50 & \\
\hline
\end{tabular}

More than $50 \%$ of both the male and female dropouts have lapsed into ignorance, because there is no need for them to read and write later in life. 
Table 11. Table indicating whether somebody prompted the respondents to continue studies.

\begin{tabular}{|c|c|c|c|c|c|}
\hline SI.No. & Response & Male respondents & $\%$ & Female respondents & $\%$ \\
\hline 1 & Yes & 39 & 78 & 22 & 44 \\
2 & No & 11 & 22 & 28 & 56 \\
\hline Total & & 50 & & 50 & \\
\hline
\end{tabular}

Higher percentage of male dropouts $(78 \%)$ was prompted to continue their studies than the female dropouts (44\%).

Table 12. Table indicating who prompted the respondents to continue their studies (details of those who prompted).

\begin{tabular}{|c|l|c|c|c|c|}
\hline SI.No. & Response & Male & $\%$ & Female & $\%$ \\
\hline 1 & Parents & 38 & 86 & 15 & 63 \\
2 & Political leaders & $\mathrm{Nil}$ & $\mathrm{Nil}$ & $\mathrm{Nil}$ & $\mathrm{Nil}$ \\
3 & Teachers & $\mathrm{Nil}$ & $\mathrm{Nil}$ & 03 & 13 \\
4 & Neighbors & 01 & 2 & $\mathrm{Nil}$ & $\mathrm{Nil}$ \\
5 & Friends & 02 & 05 & $\mathrm{Nil}$ & $\mathrm{Nil}$ \\
6 & Siblings & 02 & 05 & 02 & 08 \\
7 & Others & 01 & 2 & 04 & 17 \\
\hline Total & & 44 & & 24 & \\
\hline
\end{tabular}

Note: Only few respondents were prompted to continue their studies. More than one persons have prompted the dropouts.

1) $86 \%$ and $63 \%$ of the male and female dropouts respectively, were prompted by their parents to continue their studies. The role of others here is negligible.

2) There is need for the voluntary organizations to work vigorously to bring the dropouts back to schools. 
Table 13. Table showing the responses regarding who should help the community to come up in life.

\begin{tabular}{|c|l|c|c|c|c|}
\hline SI.No. & Response & Male & $\%$ & Female & $\%$ \\
\hline 1 & Self & 47 & 94 & 35 & 70 \\
2 & Political leadership & $\mathrm{Nil}$ & $\mathrm{Nil}$ & $\mathrm{Nil}$ & $\mathrm{Nil}$ \\
3 & Community Leadership & 02 & 04 & 01 & 02 \\
4 & Don't Know & 01 & 02 & 04 & 08 \\
\hline Total & & 50 & & 50 & \\
\hline
\end{tabular}

Highest percentage of both male (94\%) and female dropouts (70\%) felt that they should help themselves for the community to come up in life. Expectations from the political leadership are $\mathrm{Nil}$, and expectations from the community leadership are negligible.

Table 14. Table providing the opinion of the respondents whether they should have continued their education

\begin{tabular}{|c|c|c|c|c|c|}
\hline SI.No. & Response & Male respondents & $\%$ & Female respondents & $\%$ \\
\hline 1 & Yes & 22 & 44 & 40 & 80 \\
2 & No & 28 & 56 & 10 & 20 \\
\hline Total & & 50 & & 50 & \\
\hline
\end{tabular}

A very important fact, which emerges here is that, a higher percentage of female dropouts (80\%) felt that they should have continued their education than the male dropouts $(44 \%)$. Here one can see that the urge among females to come up is more.

Table 15. Table indicating whether the respondents regret for not continuing their education.

\begin{tabular}{|c|c|c|c|c|c|}
\hline SI.No. & Response & Male respondents & $\%$ & Female respondents & $\%$ \\
\hline 1 & Yes & 23 & 46 & 39 & 78 \\
2 & No & 22 & 44 & 10 & 20 \\
3 & Don't know & 05 & 10 & 01 & 02 \\
\hline & & 50 & & 50 & \\
\hline
\end{tabular}

Higher percentages of female dropouts regret dropping out from school than male dropouts. Here one can note that the urge among the females to learn is more than males. 
Table No.16-Table indicating the opinion of the respondents whether education is necessary to come up in life.

\begin{tabular}{|c|c|c|c|c|c|}
\hline SI.No. & Response & Male respondents & $\%$ & Female respondents & $\%$ \\
\hline 1 & Yes & 34 & 68 & 40 & 80 \\
2 & No & 07 & 14 & 01 & 02 \\
3 & Don't know & 09 & 16 & 09 & 18 \\
\hline & Total & 50 & & 50 & \\
\hline
\end{tabular}

1) Of the total male dropouts interviewed, $68 \%$ felt that education is necessary to come up in life, 14\% said it is not, $16 \%$ do not know anything about it.

2) Of the total female dropouts interviewed, $80 \%$ felt that education is necessary to come up in life, $2 \%$ felt that it is not necessary, $18 \%$ said they do not know anything about it.

3) It is a very interesting fact to note that, higher percentage of females has said the education is necessary to come up in life than the males. Infact $14 \%$ of the male dropouts have said that education is not necessary to come up in life.

Table No.17-Table showing the opinion of the respondents about the girl's

\begin{tabular}{|c|c|c|c|c|c|}
\hline SI.No. & Response & Male respondents & $\%$ & Female respondents & $\%$ \\
\hline 1 & Desirable & 30 & 60 & 44 & 88 \\
2 & Undesirable & 12 & 24 & 08 & 16 \\
3 & Don't know & 08 & 16 & 01 & 02 \\
\hline & Total & 50 & & 50 & \\
\hline
\end{tabular}

A glaring fact, which emerges here, is that, lower percentage of male dropouts are in favour of girl's education than the females. $24 \%$ of the male dropouts are not in favour of girl's education.

\section{To the question what is the desirable level of education for girls?}

More than $90 \%$ including those who are not in favour of girl's education said that $10^{\text {th }}$ standard is the desirable level of education for girl. Less than 10\% said it could be college, II Puc, Doctor, Engineer, Teacher etc. 
Table No 18 -Table indicating opinion of the respondents whether the girl should be allowed to acquire as much education as a boy.

\begin{tabular}{|c|c|c|c|c|c|}
\hline SI.No. & Response & Male respondents & $\%$ & Female respondents & $\%$ \\
\hline 1 & Yes & 15 & 30 & 27 & 54 \\
2 & No & 20 & 40 & 20 & 40 \\
3 & Don't know & 15 & 30 & 03 & 06 \\
\hline & Total & 50 & & 50 & \\
\hline
\end{tabular}

It is to be noted that higher percentage of female dropouts are in favour of girls acquiring as much education as their male counterparts, than male dropouts.

Table No.19-Table indicating opinion of the respondents whether the girl's education will help her in looking after her family in a better way.

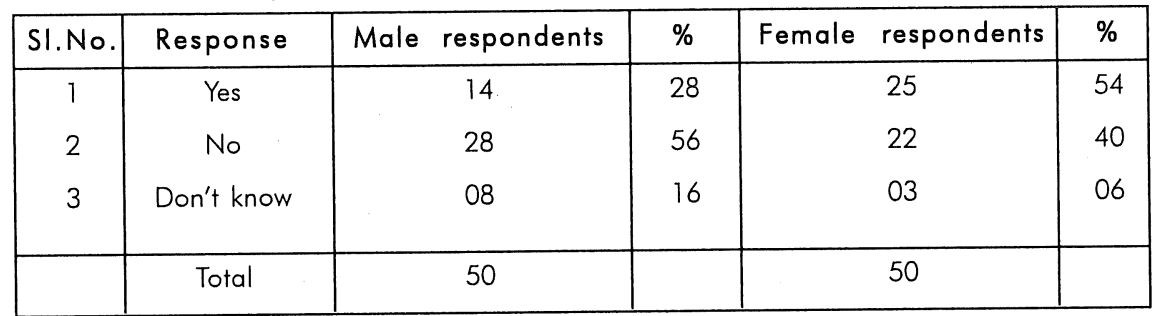

A very glaring fact, which emerges here, is that higher percentage of female dropouts $(54 \%)$ feels that education helps a girl to look after her family in a better way than their male counterparts (28\%).

Table No.20 -Table indicating whether the respondents have read Quran.

\begin{tabular}{|c|c|c|c|c|c|}
\hline SI.No. & Response & Male respondents & $\%$ & Female respondents & $\%$ \\
\hline 1 & Yes & 11 & 22 & 25 & 50 \\
2 & No & 26 & 56 & 05 & 10 \\
3 & Still Learning & 03 & 06 & 20 & 40 \\
\hline & Total & 50 & & 50 & \\
\hline
\end{tabular}

A higher percentage of female dropouts have read and are still learning Quran than their male counterparts. This shows that the community gives more importance to the religious education of a girl than boy. 
Table 21. Table showing whether the respondents comprehend the meaning of Quranic verses (this question was addressed to those who had read Quran).

\begin{tabular}{|c|c|c|c|c|c|}
\hline SI.No. & Response & Male respondents & $\%$ & Female respondents & $\%$ \\
\hline 1 & Yes & Nil & Nil & Nil & Nil \\
2 & No & 11 & 100 & 25 & 100 \\
\hline & Total & 11 & & 25 & \\
\hline
\end{tabular}

1) None of the dropouts, both male and female comprehend the meaning of Quranic verses, even if they have read Quran.

2) This question is included because Quran often emphasizes the importance of education for both male and female, and Quran is read in its Arabic version only.

\section{Parents' responses} Table 22. Table indicating reasons for the dropping out of their wards, as given
by the parents.

\begin{tabular}{|c|l|c|c|c|c|}
\hline $\begin{array}{c}\text { SI. } \\
\text { No. }\end{array}$ & \multicolumn{1}{|c|}{ Response } & $\begin{array}{c}\text { Male } \\
\text { respondents }\end{array}$ & $\%$ & $\begin{array}{c}\text { Female } \\
\text { respondents }\end{array}$ & $\%$ \\
\hline 1 & Economic Compulsion & 08 & 16 & 12 & 24 \\
2 & Loss of interest & 27 & 54 & 09 & 18 \\
3 & Parent's force & 03 & 06 & 15 & 30 \\
4 & Bad Company & 08 & 16 & 03 & 06 \\
5 & Household chores & $\mathrm{Nil}$ & $\mathrm{Nil}$ & 04 & 08 \\
6 & Others & 04 & 08 & 7 & 14 \\
\hline & Total & 50 & & 50 & \\
\hline
\end{tabular}

1) It may be noted that loss of interest is one of the major reasons for the males to dropout, then comes bad company and economic compulsions, household chores is not at all the reason for dropping out.

2) For the female dropouts, parent's force is one the major reasons for dropping out, and then comes economic compulsions, loss of interest, other reasons, household chores and bad company. It is an interesting fact to be noted that higher percentage of female dropouts are because of economic compulsions than their male counterparts. 
3) Under the reason other may be included the reasons such as no eighth standard close to the respondent's house, the boy was not studying well, underwent appendix operation, stammering problem of the dropout, difficulty in climbing the buses, not able to read and write, wasting time in playing cricket and not going to school made the parents to make him work in the mechanic shop, inability to pay fee, children's earning supplement the family income, attitude that Government does not do anything about the Muslims, education is no guarantee for securing a Government job, failing two times in the same class, falling sick, change of the medium of instruction from Urdu to Kannada leading to loneliness of the boy, could not make friends with Kannada speaking boys and inability to pick up Kannada medium from Urdu, during the course of studies. Such parents might have done well to admit their wards in Kannada medium from class 1 .

4) For female dropouts, reasons such as Brother's accident, Mother's T.B., mother's death, marriage being arranged, in several cases brothers have forced the girls to leave school. Large family, father deserting the family leading to the discontinuation of children's education and forcing them to work, the girl not able to cross the road, girls attaining puberty, school insisting on wearing short skirt uniform, change of the medium of instruction to Kannada leading to loneliness of the girl could not make friends with Kannada speaking girls (these other reasons are given both by the parents and the dropouts in their respective interviews).

Table 23. Table showing whether the parents have a cordial relationship.

\begin{tabular}{|c|c|c|c|c|c|}
\hline $\begin{array}{c}\text { SI. } \\
\text { No. }\end{array}$ & Response & $\begin{array}{c}\text { Parents of } \\
\text { Male respondents }\end{array}$ & $\%$ & $\begin{array}{c}\text { Parents of } \\
\text { Female respondents }\end{array}$ & $\%$ \\
\hline 1 & Yes & 18 & 36 & 22 & 44 \\
2 & No & 32 & 64 & 28 & 56 \\
\hline & Total & 50 & & 50 & \\
\hline
\end{tabular}

The glaring fact to be noted is that almost $64 \%$ of the male dropouts' parents and $56 \%$ of the female dropouts' parents have said that there is no cordial relationship between the husband and wife. Naturally unhappy homes, not favourable for education become a reality. 
Table 24. Table showing whether the father of the respondent has any bad habits.

\begin{tabular}{|c|c|c|c|c|c|}
\hline $\begin{array}{l}\text { SI. } \\
\text { No. }\end{array}$ & Response & $\begin{array}{l}\text { Parents of } \\
\text { Male respondents }\end{array}$ & $\%$ & $\begin{array}{l}\text { Parents of } \\
\text { Female respondents }\end{array}$ & $\%$ \\
\hline 1 & Yes & 19 & 38 & 20 & 40 \\
\hline 2 & No & 31 & 62 & 30 & 60 \\
\hline & Total & 50 & & 50 & \\
\hline
\end{tabular}

1) An important fact to be noted here is that $38 \%$ of the male dropouts' mothers and $40 \%$ of the female dropouts' mothers have reported bad habits of the father.

2) The mothers, who reported bad habits of the fathers, specified the bad habits as drinking, having one more wife, leaving their family and going away to another woman etc. The parents who reported bad habits of the fathers were mothers.

Table 25. Table showing whether both the parents are interested in the child's education.

\begin{tabular}{|c|c|c|c|c|c|}
\hline $\begin{array}{c}\text { SI. } \\
\text { No. }\end{array}$ & Response & $\begin{array}{c}\text { Parents of } \\
\text { Male respondents }\end{array}$ & $\%$ & $\begin{array}{c}\text { Parents of } \\
\text { Female respondents }\end{array}$ & $\%$ \\
\hline 1 & Yes & 37 & 74 & 07 & 14 \\
2 & No & 13 & 26 & 43 & 86 \\
\hline & Total & 50 & & 50 & \\
\hline
\end{tabular}

A glaring fact which emerges here is that $86 \%$ of the female dropouts' parents reported that both the parents are not interested in their ward's education, only $14 \%$ said that both the parents are interested in their wards' education, whereas $74 \%$ of the male dropouts' both the parents take interest in their ward's education, and only $26 \%$ of the male dropouts' parents reported that both the parents are not interested in their ward's education. 
Table 26. Table showing which parent is not interested in the child's education. (If the above answer is no).

\begin{tabular}{|c|c|c|c|c|c|}
\hline SI. & Response & $\begin{array}{c}\text { Parents of } \\
\text { Male respondents }\end{array}$ & $\%$ & $\begin{array}{c}\text { Parents of } \\
\text { Female respondents }\end{array}$ & $\%$ \\
\hline 1 & Father & 02 & 15 & 06 & 14 \\
2 & Mother & 08 & 62 & 17 & 40 \\
3 & Both & 03 & 23 & 16 & 37 \\
4 & Others (brother) & $\mathrm{Nil}$ & Nil & 03 & 07 \\
\hline & Total & 13 & & 43 & \\
\hline
\end{tabular}

1) $15 \%$ of the male dropout's fathers are not interested in their ward's education, $62 \%$ of mothers, $23 \%$ both the parents, Nil others (brother) are not interested in their ward's education.

2) $14 \%$ of the female dropout's fathers are not interested in their ward's education $40 \%$ of mothers, $37 \%$ of both, $7 \%$ others (brother).

Table 27. Table showing whether discontinuation of the child's education has helped the parents.

\begin{tabular}{|c|c|c|c|c|c|}
\hline $\begin{array}{c}\text { SI. } \\
\text { No. }\end{array}$ & Response & \multicolumn{2}{|c|}{$\begin{array}{c}\text { Parents of } \\
\text { Male respondents }\end{array}$} & $\%$ & \multicolumn{2}{c|}{$\begin{array}{c}\text { Parents of } \\
\text { Female respondents }\end{array}$} & $\%$ \\
\hline 1 & Yes & 39 & 78 & 37 & 74 \\
2 & No & 11 & 22 & 13 & 26 \\
\hline & Total & 50 & & 50 & \\
\hline
\end{tabular}

Percentage of parents who said they have benefited by their ward's dropping out is more or less same for both the male and female dropouts. Higher percentage of both male and female dropouts' parents reported that they have benefited by their ward's discontinuation of education. 
Table 28.Table showing in what way the child's discontinuation of education helped the parents (Relates to only those parents who felt their ward's dropping out has helped them).

\begin{tabular}{|c|l|c|c|c|c|}
\hline $\begin{array}{c}\text { SI. } \\
\text { No. }\end{array}$ & \multicolumn{1}{|c|}{ Response } & $\begin{array}{c}\text { Parents of } \\
\text { Male } \\
\text { respondents }\end{array}$ & $\%$ & $\begin{array}{c}\text { Parents of } \\
\text { Female } \\
\text { respondents }\end{array}$ & $\%$ \\
\hline 1 & Adding to family income & 33 & 85 & 07 & 19 \\
2 & Helping in household chores & $\mathrm{Nil}$ & $\mathrm{Nil}$ & 30 & 81 \\
3 & Others (Learning work) & 06 & 15 & $\mathrm{Nil}$ & $\mathrm{Nil}$ \\
\hline & Total & 39 & & 37 & \\
\hline
\end{tabular}

$85 \%$ of the male dropouts' discontinuation of education helped their parents in adding to the family income, only $19 \%$ of the female dropouts' discontinuation of education helped in adding to the family income, as reported by their parents.

Whereas $81 \%$ of the females dropping out helped their families in helping with household chores. $10 \%$ of the male dropouts are learning work none of the female dropouts are learning work.

\section{Let us discuss the measures for the educational advancement of the community}

Nursery School: One of the major missing links identified in education of these children is absence of a nursery school. The community leaders and people of the area should try to secure an anganawadi sanctioned for their areas. Voluntary organizations of the community can organize such nursery schools.

Role of School Development and Monitoring Committee (SDMC): Most of the children go to government schools in Urdu medium. Each govt. primary school has a School Development and Monitoring Committee (SDMC) in which parents representatives among other local people's representatives are there. These committees should become active and do interalia the following things:

All issues with Government departments such as filling up of vacant posts, supply of teaching and learning material (TLM), prompt supply of textbooks etc. should be taken up with the departmental officers.

Should watch the teaching and learning process in school, by making surprise visits to classes. The SDMCs should also randomly check homework given by 
teachers and compliance of doing the same on the part of the students. In brief these committees should improve the teaching/learning capacity of the schools.

These committees should also raise donations from the public to improve facilities in the school.

Motivational effort: There is need for organized motivational effort from outside the families, by voluntary organizations consisting of members from well to do and well educated sections, of the Muslim society. Each of these organizations should take up one or two localities of the type, which are studied under this report. They should survey the whole locality by; means of a family based census of each family collecting all relevant socio-economic and educational details and preserve familywise data on their computer, before commencement of their work in any locality. This data should be periodically updated. The volunteers of the organization should periodically visit the families and study the problems connected with educational needs and help the students to resolve such needs.

organization of continuing education out of school hours in govt. schools or private and aided schools will succeed. The state government can start 'continuing education' in timings convenient to dropouts, which coincides with out of school hours to learn up to $10^{\text {th }}$ standard and pass the same. It is learnt that Akshara Foundation is doing good work to educate the gainfully employed dropouts with the permission of the persons with whom they are working. We need to make more branches of Akshara Foundation working in Muslim localities also.

Imparting skills in education: Training in skills while at school for improving employability appears to be necessary. Therefore the syllabus for vocationalisation of education should be got formulated by education department by drafting a panel of experts who are conversant with the employment needs of a dynamic economy. It would perhaps be appropriate to quote from Dr. Amartya Sen, the Nobel laureate to indicate how China is using its educated manpower by giving them appropriate skills. In his book entitled 'The Argumentative Indian' published by Penguin Books Ltd in 2005, on page $198 \mathrm{Dr}$ Sen states, The products that China exports to the outside world include a great many that are made by not particularly highly skilled labour, but schooled and literate labour. Nevertheless their production generates much employment with great deal of income going to poorer sections of the community. Utilization of the world market for such exports requires production according to specification, quality control and an informed consciousness of the economic tasks involved. Good school education is central to these tasks. Similarly good health is extremely important if productive effort and economic schedules are not to be affected by illness and intermittent absence'. 
Female Education: Though female education is considered desirable by both respondents, and parents of respondents but when asked whether girls education is as important as boys education, a big majority of parents of both boys and girls as well as a majority of boys and (40\%) of girl dropouts also felt relatively girls education is not so important. This speaks of the Muslim society's mindset. This has to undergo a change, if the community has to progress. In fact from all available facts in this research the girls, wherever they have been allowed to study have proved to be better than boys. Thus this subtle urge on the part of the girls to study should be used by voluntary organizations to motivate the parents to educate more and more girls.

Voluntary Efforts: The Researcher has placed great reliance on voluntary efforts on the part of well to do sections of the Muslim community. Although as seen from table 45 there is at present Nil expectation from political leadership and negligible expectation from community leadership. This leadership has to emerge and voluntary efforts organized. Therefore the Muslim intellectuals and well to do sections of Muslim society should come together and raise funds and take proactive role in bringing up their brethren from the depths of illiteracy, lack of skills and help them to do better in life. Unless such voluntary efforts are mounted, it is difficult to foresee the community to rise and face the challenges, which advancing economic growth will bring in its wake.

It is compulsory for the Govt. school teachers to conduct dropout survey every year, to bring these dropouts back to school and give them extra coaching, during summer vacation. It has come to the notice of the researcher that the teachers do not report any dropouts in their areas, to avoid working on holidays if dropouts are listed by them. There is need to have some teacher-friendly policies with financial and promotional incentives attached to them to encourage teachers to bring the dropouts back to school. In fact the education dept. would do well to advise foundations like Azim Premii foundation to earmark some funds for incentivising teachers to re-educate the dropouts and make them show definite results by enabling some percentage of dropouts to pass $10^{\text {th }}$ standard examinations as external candidates.

Friday sermons in mosques can concentrate on social issues afflicting Muslim community including the importance given to education by the religion. This has the potential to give rise to a renaissance in the Muslim community.

Educational backwardness and economic backwardness of parents as the reasons for creating circumstantial milieu, which leads to dropouts in the community. Therefore we will marginally touch this issue. We will confine ourselves to the type of jobs done by target group which we have surveyed. 
The following suggestion may be taken note of for upliftment of economic condition of the community:

- Large majority of the Muslims surveyed are pursuing skilled or unskilled occupations. They do not have their own units and work for others at meager wages. These artisans/mechanics need to be helped to get self employed to earn more.

- Self-employment calls forth for finances as well as organizational ability to manage their enterprises, however small.In so far as state Government is concerned, it has a Karnataka State Minorities Development Corporation, which provides margin money for worthwhile projects and links them to banks for loans. There are also several benefits given by the Dept. of minorities, Dept. of women and child welfare along with its Women Development Corporation also gives assistance of margin money etc and provides linkage to banks in schemes of self employment like udyogini and stree shakti to women irrespective of religion.

-. Then there are several anti-poverty programmes of the Government about which awareness is not there in the weaker sections of the Muslim community. Awareness camps should be organized in Muslim localities so that they may avail of the benefits.

- The Muslim voluntary organizations should form self help groups of these sections and help them to secure benefits of finance from financial institutions and help them to organize their enterprises in an effective manner.

- As suggested by Asghar Ali Engineer in one of his articles we can have Zakat Boards in every state with persons of known integrity heading them. Since Zakat under which every Muslim who has savings after meeting his expenses has to contribute two and half percent of savings for charity to the poor and needy, will go a long way in meeting the financial needs of small enterprises of these artisans.

In brief, the community will have to learn to stand on its own feet and make itself a rightful partner in India's economic and educational progress. 


\section{References}

1. Asghar Ali Engineer: An Article- Indian Muslims and Education.

2. Asghar Ali Engineer: An Article-Muslim middle class and its role(secular perspectives May 16-31 2001) web edition 1999-2001 Ingrid H.Shafer

3. Asghar Ali Engineer: An Article-Islamic and the crisis of Modernism (Islam and modern age Jan 2002)

4. Asghar Ali Engineer: An Article-Islam on the eve of $21^{\text {st }}$ century.

5. A.S. SeethaRamu: Education in Slums Ashish Publishing House, New Delhi

6. B. Rahamathulla: What ails Muslims for Education in India; some thoughts -An Article in Indian Muslims precepts and Practices-Edited by Noor Mohammad.

6. Dr. M.M.Siddiqui: Incidence of Divorce among Indian Muslims (Institute of Objective studies)

7. Dr. Amartya Sen: Argumentative Indian-Published by Penguin Books Ltd.

8. Dr. Gita sen: Gender and Human development. Investing in Human development (Karnataka Human development Report-2005) Planning and statistics Department Government of Karnataka.

9. Dr. P. R. Panchamukhi: Literacy and Education Investing in Human development (Karnataka Human development Report-2005) Planning and statistics Department Government of Karnataka.

10. Ishtiaque Danis: Empowerment of Muslim youth in India (Institute of Objective Studies in India)

11. K.G. Munshi: Socio-Economic Profile of Indian Muslims -A case study of Delhi (Institute of Objective Studies)

12. Maqbool Ahmed Siraj: An Article- Lest the IT. Revolution Bypass Muslims (Islamic VoiceMonthly News letter)

13. Mohammad Shariff Khan: An Article-Development of Higher Education with special reference to Muslims- (Education and Muslims in India since Independence - Edited by A.W.Qadri, Riaz Shakir Khan, Mohammad Akhter Siddique (Institute of Objective Studies, New Delhi)

14. Rokaiya Begum: An article- Education and the Muslim women (Indian Muslims: Precepts and practices-edited by Noor Mohammed, Rawat Publications-Jaipur and New Delhi

15. Sachar committee report 2006

16. Sekh Rahim Mondel: Educational Status of Muslims-Problems, Prospects and Priorities- Inter India Publications, 1997, New Delhi.

17. Socio-economic \& Report of High Power Committee Educational Survey-1994 Karnataka Minorities of Religious minorities in Commission Karnataka.

18. Yogender Sikand: Muslim Women most backward (Paper submitted in a Seminar at Mumbai) 